\title{
LOCAL DENSITY AND FOREIGN SUBSIDIARY PERFORMANCE
}

\author{
STEWART R. MILLER \\ University of Texas at Austin \\ LORRAINE EDEN \\ Texas A \& M University
}

\begin{abstract}
Local density (the number of firms vying for similar resources in a local environment) has been overlooked in explaining foreign subsidiary performance. This study drew upon the concepts of liability of foreignness and density dependence to examine how local density within a host country affected performance-directly and indirectlythrough effects on market experience and strategic conformity. We found that local density was negatively related to foreign subsidiary performance and that market experience was less beneficial in high-density environments. Strategic conformity enhanced performance in low-density environments but adversely affected performance in high-density environments.
\end{abstract}

Multinational enterprise (MNE) theorists have long argued that foreign subsidiaries face disadvantages in a host country, compared to domestic firms (Hymer, 1960/1976; Zaheer, 1995). Zaheer referred to this phenomenon as the "liability of foreignness," defining it as "the additional costs of doing business abroad that result in a competitive disadvantage for an MNE subunit" (1995: 342). This literature suggests that such liability varies across host countries and that the greater the liability of foreignness, the worse should be foreign subsidiary performance-unless a parent MNE engages in offsetting activities or has superior resources to overcome these additional costs (Dunning, 1977; Zaheer \& Mosakowski, 1997). Understanding what additional activities and/or superior resources can overcome liability of foreignness and improve performance is an important research problem not only for international management scholars, but also for corporate executives and subsidiary managers of MNEs. Market experience in a host country and isomorphism (being similar to local firms) are

Earlier versions of this paper were presented at the 2003 Academy of International Business meetings, the 2004 Organization Science Winter Pre-conference, and in a faculty seminar at the University of Illinois. The authors thank Associate Editor Marshall Schminke and three anonymous reviewers for their comments and suggestions. Valuable comments were also received from Jim Fredrickson, Andy Henderson, Michael Hitt, George Huber, Tatiana Kostova, Julie Irwin, Arie Lewin, Dan Li, John Mezias, Lilach Nachum, and James Westphal. The authors appreciate research assistance provided by Kevin Dickson, Don Lange, and Ashu Manohar. We are also indebted to Pat Relich of the FDIC. perhaps the best-known methods for overcoming liability of foreignness (Kostova \& Zaheer, 1999; Zaheer \& Mosakowski, 1997).

Not only are there additional costs to operating abroad, but also, host country environments differ across and within countries, creating unique challenges for foreign subsidiaries that must simultaneously adapt to a particular local environment while accommodating pressures for global integration within an MNE network (Kostova \& Zaheer, 1999; Xu \& Shenkar, 2002). In our study, we focused on a concept that has been ignored to date in studies of liability of foreignness and foreign subsidiary performance: local density. Density is a measure of the number of firms in a population (for example, an industry) vying for similar resources (Hannan \& Carroll, 2000). Because firms in an industry often cluster in locations such as cities that offer agglomeration economies and more munificent resources, density varies across geographic areas within a country (Porter, 1990). Since competition within an industry can be localized (Baum \& Mezias, 1992; Baum \& Singh, 1994; Hannan, Carroll, Dundon, \& Torres, 1995), we argue it is useful for scholars to adopt a more granular concept of density-local density, which we define as the number of firms vying for similar resources in a local environment-particularly in industries, such as services, that require firms to be close to their customers (Porter, 1986; UNCTAD, 2004).

Our objective in this study was to answer the following research question: How does local density affect foreign subsidiary performance? To answer this question, we developed a theoretical model that builds upon the liability of foreignness and density dependence literatures. 
According to density dependence scholars, density changes over time as a population matures (Baum \& Singh, 1994; Hannan \& Carroll, 1992, 2000). Institutional pressures tend to be high early in the life of a population but give way to competitive pressures as the population matures. This observation suggests that firms in mature industries face stronger competitive and weaker institutional pressures than do their counterparts in new industries. If competition is localized within an industry, differences in the local density of a mature population should reflect differences in local competitive pressures at any point in time, all other things being equal.

When a foreign subsidiary locates in a host country, its market may be local, national, regional, or global, depending on the mandate given the subsidiary by its parent. Most subsidiaries have local or national mandates, particularly in service industries (Tschoegl, 1987; UNCTAD, 2004). Building on previous work on density dependence, we hypothesize that foreign subsidiaries that locate in highdensity environments face stronger competitive pressures than those located in low-density environments, suggesting that local density negatively affects foreign subsidiary performance.

According to research on liability of foreignness, local market experience can reduce this liability and improve foreign subunit performance in a host country (Kostova \& Zaheer, 1999; Zaheer \& Mosakowski, 1997). We contend that the benefits of market experience, in terms of accumulating local knowledge and becoming embedded in the local environment, depend on the local density of the environment in which a subsidiary operates. Thus, local density moderates the relationship between market experience and foreign subsidiary performance.

Deephouse (1999) found that domestic firms achieved better performance in their home markets when they balanced pressures to be similar or different from their rivals. Strategic conformity reflects the degree to which a firm's strategy corresponds to the average strategic profile of industry rivals (Finkelstein \& Hambrick, 1990). In our article, we extend Deephouse's work to the international level by examining the dual pressures on foreign subsidiaries to be similar to, or different from, local competitors in a host country. We also contribute to this literature (e.g., McNamara, Deephouse, \& Luce, 2003; Mezias \& Mezias, 2000) by theorizing that, for foreign subsidiaries, local density affects the relative pressures to conform to, and differentiate from, local firms by influencing the range of legitimate strategies; that is, local density moderates the relationship between strategic con- formity and foreign subsidiary performance. Our analysis helps to resolve the "differentiation versus conformity" dilemma facing foreign subsidiaries with a theoretical argument for a relationship between strategic conformity and foreign subsidiary performance that is contingent on local density.

In sum, we examine how local density within a host country affects foreign subunit performance directly, and also indirectly, through its effects on market experience and strategic conformity. By understanding the effect of local density and its relationships with market experience and strategic conformity, our study builds on and extends the concept of the liability of foreignness expounded in Zaheer (1995), Zaheer and Mosakowski (1997), and Nachum (2003), and the concept of strategic conformity in Deephouse (1999).

\section{THEORY DEVELOPMENT}

In our theory development, we draw on the density dependence literature to forward local density as a moderator of foreign subsidiary performance. We pay special attention to theoretical implications for service firms, for which geographic proximity is critical to building customer relationships.

\section{Liability of Foreignness}

Scholars have theorized that multinational enterprises incur costs not faced by domestic firms that adversely affect the performance and survival of their foreign subsidiaries (Delios \& Beamish, 2001; Eden \& Miller, 2004; Mitchell, Shaver \& Yeung, 1994). Zaheer (1995) labeled these costs "liability of foreignness." A body of literature on liability of foreignness has grown steadily (e.g., Eden \& Miller, 2004; Kostova \& Zaheer, 1999; Mezias, 2002; Miller \& Parkhe, 2002; Nachum, 2003; Zaheer \& Mosakowski, 1997). In addition, other studies have examined the additional challenges faced by foreign subsidiaries without using the term "liability of foreignness" (e.g., DeYoung \& Nolle, 1996; Li, 1995; Mitchell, Shaver, \& Yeung, 1994; Shaver, Mitchell, \& Yeung, 1997).

In the liability of foreignness literature, for example, Zaheer (1995) and Zaheer and Mosakowski (1997) concluded that exchange trading operations of foreign subsidiaries had a lower survival rate than those of domestic rivals. Miller and Parkhe (2002) found that foreign subsidiaries performed more poorly than domestic firms. Mezias (2002) concluded that foreign subsidiaries faced more lawsuits that their domestic rivals.

It is important to note that we distinguish liability of foreignness from liability of newness (Singh, 
Tucker, \& House, 1986). Liability of newness refers to the challenges following the birth of an organization, whereas liability of foreignness refers to the challenges that a foreign subunit faces in a host country. These challenges not only apply at the time of birth (establishment) of a foreign subunit but are also ongoing (Hymer, 1976; Zaheer, 1995). Liability of foreignness is defined with respect to spatial costs (that is, distance-related costs), unfamiliarity costs, host country government costs, and home country government costs (Zaheer, 1995). New domestic firms may face legitimacy challenges in their early years, but they do not encounter these four types of costs. Thus, despite parallels between these two concepts, we see them as distinct.

At the heart of the challenge for foreign subsidiaries is how to overcome liability of foreignness. The competitive perspective has stressed that firmspecific resources (for example, host country market experience and home-based advantages) enable a foreign subsidiary to differentiate itself from domestic firms and improve its performance in a host country (e.g., Dunning, 1977; Porter, 1990). The institutional perspective, on the other hand, emphasizes that isomorphism can reduce liability of foreignness and improve performance (Rosenzweig \& Singh, 1991; Zaheer, 1995). Isomorphic behavior may reflect conformity with local regulations or with pressures to adapt products to local tastes and preferences. MNEs are rewarded for isomorphism with increased legitimacy, resources, and survival capabilities in host countries (Kostova \& Zaheer, 1999). Research on liability of foreignness has not identified which course of action, competitive or institutional, is preferable for foreign subsidiaries. Thus, there is an unresolved tension with respect to overcoming liability of foreignness: should a foreign subsidiary be similar to or differentiate itself from local firms?

\section{Local Density}

Competitive and institutional pressures have also been important to researchers examining density dependence, who have argued that these pressures vary in strength depending on local density (Hannan \& Carroll, 1992, 2000). The capacity of a population's members to acquire resources depends on legitimization of the members by those who control resources (Hannan \& Freeman, 1987). Thus, institutional pressures for cognitive legitimacy (Ruef \& Scott, 1998) tend to be high early in the life of a population, when density is low.

As a population grows, the interdependence among its members becomes competitive (Baum \& Singh, 1994). Increases in the number of organiza- tions depending on the same finite pool of resources deplete the resource pool, resulting in lower growth rates of organizations, individually and collectively. Accordingly, legitimacy pressures are stronger than competitive pressures in low-density environments, but they become relatively weaker as density increases. In large, mature populations, competitive pressures should dominate institutional pressures. Empirical studies have confirmed that density has a U-shaped relationship with respect to mortality rates and an inverted Ushaped relationship with founding rates (Carroll \& Hannan, 1989; Hannan \& Freeman, 1977).

In the present study, we studied density dependence in a mature population-the banking sector of an industrialized country, the United States. A key feature of the banking sector and of service sectors in general, the need to be close to customers, makes local density a more appropriate lens than national density (Hannan, 1991). Since banking is a mature industry, the cognitive legitimacy of the population is not a central concern. Institutional pressures can remain strong, but they tend to be normative or regulative in banking, as Deephouse (1999) and Zaheer (1995) noted. ${ }^{1}$ Traditionally, the density dependence literature has focused on competition and legitimacy within a population over the life of the population. Applied to mature industries such as banking, density dependence suggests that competitive pressures should dominate institutional pressures, whereas the reverse should be the case for the banking industry in developing countries or emerging markets.

We expect increases in local density to be associated with increases in competitive pressures. As competition intensifies, there is greater pressure on firms to be cost effective and to offer attractive pricing in order to prevent customers from switching to rival firms. Thus, "rents are squeezed" as competition increases within an industry; at the limit (perfect competition), firms earn only normal returns.

Prior research has concluded that differences in home country competitiveness affect foreign sub-

\footnotetext{
${ }^{1}$ Later in a population's life, density may decrease, but that does not mean that legitimacy of the population is declining. For instance, data reported by Miller and Parkhe (2002) indicated that the number of banks in the four most populous EU countries (France, Germany, Italy, and the United Kingdom) are quite different, yet few would claim that this fact indicates different levels of legitimacy. Similarly, electric generation and cable are industries in which density is low but cognitive legitimacy is high. We are indebted to a reviewer for this point.
} 
sidiaries' performance relative to other foreign subsidiaries (Miller \& Parkhe, 2002). We can extend this finding to differences in competitive pressures within a host country. For a foreign subsidiary, higher local density, reflecting higher competitive pressures, suggests that rents to the subsidiary's home-based advantages should dissipate. Thus, higher local density should make it more difficult for a foreign subunit to achieve and maintain above-normal returns to its home-based advantages in a foreign country. We therefore hypothesize:

Hypothesis 1. Local density is negatively related to foreign subsidiary performance.

\section{Market Experience and Local Density}

Foreign subsidiaries encounter unfamiliarity and discrimination costs associated with operating in a host country. Over time, liability of foreignness is expected to decline as a foreign subsidiary accumulates market knowledge regarding customer preferences, suppliers, and institutions (Johanson \& Vahlne, 1977; Tschoegl, 1987; Zaheer \& Mosakowski, 1997). Market experience enables the foreign subsidiary to make more informed decisions in the host country (Johanson \& Vahlne, 1977; Tschoegl, 1987).

Kostova and Zaheer (1999) suggested that insufficient information about a foreign subsidiary on the part of host country customers, suppliers, and institutions can lead to discriminatory treatment of the foreign subsidiary, such as unwillingness to conduct business with it or stereotyping foreign subsidiaries as inferior to domestic firms. With market experience, the foreign subsidiary becomes increasingly familiar within the host country environment, resulting in less stereotyping and discriminatory treatment and enabling the foreign subunit to become more embedded in the local environment (Kostova \& Zaheer, 1999; Zaheer \& Mosakowski, 1997). Thus:

Hypothesis 2. Market experience is positively related to foreign subsidiary performance.

The interaction between local density and market experience has been overlooked in previous explanations of foreign subsidiary performance. Although it takes time for foreign subunits to accumulate local knowledge and become embedded in local environments, we contend that this process varies by location since some local environments, namely high-density environments, are more cosmopolitan than others. Thus, we contend that local density moderates the relationship between market experience and foreign subsidiary performance; that is, this relationship is weaker in high-density environments.

Merton (1957) used the term "cosmopolitanism" to reflect the tendency of people to orient themselves beyond their local community - to have an international rather than a local perspective. Cosmopolitans, in general, tend to be more open to foreign cultures and less affected by cultural biases, even if they value their local culture or are ethnocentric with respect to consumption (Hannerz, 1990; Shimp \& Sharma, 1987). Although Merton associated cosmopolitanism with people, some organizational scholars have adapted this notion by suggesting that some geographic areas are more cosmopolitan than others (Beaverstock, Smith, \& Taylor, 2003). This suggests that discrimination against foreign subsidiaries by local customers, suppliers, and institutions is less likely to arise, and liability of foreignness should be lower, in more cosmopolitan environments.

Scholars have also linked cosmopolitanism to environments associated with higher levels of competitive pressure-that is, high-density environments (Cannon \& Yaprak, 2002). As competitive pressures intensify, firms need to be efficient in their activities and more receptive to new "best practices," which may come from outside a local culture. Thus, the increased competitive pressures arising in high-density environments also promote a more cosmopolitan orientation in these local environments. High-density environments where firms are clustered, including world cities such as London, New York, and Tokyo, tend to have a greater degree of cosmopolitanism in terms of their norms and practices than low-density environments (Beaverstock et al., 2003; Nachum, 2003). Although there may be subtle differences in local conditions and regulations, business practices (especially best practices) in high-density environments are likely to be imported from other parts of the world, resulting in an international orientation rather than a local one.

Therefore, in general, business practices in highdensity environments should be more similar-even to high-density environments in other countriesthan to practices in low-density environments within the same host country. As a result, multinational enterprises can readily translate accumulated knowledge from operating in other high-density markets throughout the world to their subsidiaries in other high-density environments. For example, banking and financial firms should more easily move between international financial centers located in different countries than between rural and urban areas in the same country. From this formulation, we conclude that, since normative differences across high-density 
environments are likely to be low, regardless of country, market experience should be less beneficial for foreign subsidiaries in high-density environments. ${ }^{2}$

Our argument parallels Johanson and Vahlne's (1977) contention that, if local market conditions are fairly homogeneous, market experience within a host country is unlikely to be essential for accumulating knowledge. Moreover, customers, suppliers, and institutions in more cosmopolitan environments are less likely to discriminate against foreign subsidiaries, making market experience a less valuable resource to a foreign subsidiary in these environments.

In addition, Barkema, Bell, and Pennings (1996) suggested that foreign subsidiaries could learn more effectively from experience in cultural environments similar to their home country environments than from experience in dissimilar environments. Although their study applied to national culture, our contention is that environments characterized by high local density, regardless of country, are inclined to be more normatively and cognitively similar to one another than to environments with low local density. As a result, the learning curve is flatter (that is, the payoff is smaller in terms of return on assets from learning based on market experience) in environments with high local density than in environments with low local density. Thus:

Hypothesis 3. Local density moderates the relationship between market experience and foreign subsidiary performance in such a way that the relationship is less positive in high-density environments.

\section{Strategic Conformity and Local Density}

Like work on liability of foreignness and density dependence, research on strategic conformity also involves a competitive versus institutional dilemma. Scholars suggest that there are dual pressures to conform with and to differ from one's competitors in the same industry (Deephouse, 1999). Deephouse proposed a balanced approach in which firms operate at the "competitive cusp" (Porac, Thomas, \& Baden-Fuller, 1989) to achieve high performance.

The conformity strategy is rooted in institutional theory tenets, according to which institutions in-

\footnotetext{
${ }^{2}$ The present study used foreign subsidiaries of service multinationals to test the hypotheses. Porter argued that the internationalization of services is the result, in part, of "similarity of service needs" in most countries (1990: 250).
}

fluence organizations to conform to practices, policies, and structures that are consistent with institutional preferences in an organization field (Meyer \& Rowan, 1977). An organizational field, defined as "those organizations that, in the aggregate, constitute a recognized area of institutional life: key suppliers, resource and product consumers, regulatory agencies, and other organizations that produce similar services or products" (DiMaggio \& Powell, 1983: 148), legitimates a range of strategies through an isomorphic process (Scott, 1995). Firms adopt strategies that they believe, ex ante, will achieve high performance, and successful ones tend to be imitated by other firms (Haveman, 1993).

Another value of conforming may derive from an oligopolistic consensus about the best way to compete in an industry in terms of "industry recipes" (Sirmon, Hitt, \& Ireland, 2007; Spender, 1989). Under an oligopolistic consensus, a firm's strategy is considered legitimate if the organizational field sanctions the strategy (Deephouse, 1999). Oliver suggested that "successful firms are those that gain support and legitimacy by conforming to social pressures" (1997: 700). Researchers have concluded that a group of firms follow a strategic norm closely, and then followers adopt the strategic norm, but less closely (Reger \& Huff, 1993). These findings suggest there is a range of strategies within which firms can be perceived as legitimate.

The fundamental argument underlying the differentiation strategy is that a firm faces less competition for resources to the extent that its strategic position overlaps the resource niche of rivals (e.g., Barney, 1991; Baum \& Mezias, 1992; Porter, 1980). Product differentiation enables firms to behave as price makers rather than as price takers in competitive markets, resulting in positive economic rents for firms that adopt different strategies than their rivals. Although the institutional perspective indicates that conformity increases legitimacy and therefore improves performance (Rosenzweig \& Singh, 1991; Zaheer, 1995), conformity to the strategies of other firms increases competition for similar resources and therefore adversely affects financial performance and increases failure rates (Baum \& Singh, 1994; Hannan, Ranger-Moore, \& BanaszakHoll, 1990).

The strategic conformity literature deals with firms in a domestic context (Deephouse, 1999; Mezias \& Mezias, 2000; McNamara et al., 2003), but its arguments can be readily extended to the international level. Since liability of foreignness negatively affects foreign subsidiaries, institutional pressures to conform are higher for this group than for local domestic firms (Eden \& Miller, 2004; Kostova \& Zaheer, 1999). Foreign subsidiaries, as out- 
siders, may be discriminated against or forced to incur additional costs to achieve organizational legitimacy in a host country. On the other hand, foreign subsidiaries are more likely to have, and to reply upon, firm-specific advantages that differ from those of local domestic firms, and therefore they are more likely to adopt different (or niche) strategies than domestic firms. Thus, theory and previous empirical evidence preclude making a directional prediction about the main effect for strategic conformity and foreign subsidiary performance.

In a low-density environment, competition for the same pool of resources is lower; however, the stigma of being foreign remains, creating pressures for foreign subsidiaries to achieve and maintain legitimacy. We therefore hypothesize that conforming to the strategies of local firms enhances foreign subsidiary performance in low-density environments. In contrast, in high-density environments, strong competitive pressures arising from high local density create an incentive to differentiate from the strategies of local firms to enhance performance. Since the stigma of being foreign plays a diminished role in high-density environments (Nachum, 2003), foreign subsidiaries can focus their strategies on responding to competitive pressures.

We contend that the effect of strategic conformity on foreign subsidiary performance is contingent upon local density. Therefore, we hypothesize that local density moderates the relationship between strategic conformity and foreign subsidiary performance. In low-density environments, strategic conformity by foreign subsidiaries, relative to local firms, is positively associated with foreign subsid- iary performance. In high-density environments, strategic conformity by foreign subsidiaries, relative to local firms, is negatively associated with foreign subsidiary performance.

Hypothesis 4a. Strategic conformity is positively related to foreign subsidiary performance in low-density environments.

Hypothesis 4b. Strategic conformity is negatively related to foreign subsidiary performance in high-density environments.

Figure 1 provides our theoretical model.

\section{METHODS}

\section{Data}

A foreign subsidiary in a given year was the unit of analysis in our study. To test our hypotheses, we examined the performance of U.S. subsidiaries of foreign commercial banks for the years 1995-98. It is important to note that the U.S. banking industry is considered highly regulated and that there are strong pressures to conform to government regulations. The strong regulatory framework created a conservative test of our hypotheses because the strategic domain of the sample industry was likely to be smaller than that of less regulated industries.

We followed DeYoung and Nolle (1996) and Miller and Parkhe (2002) in focusing on foreignowned banking subsidiaries rather than branches. Bank branches are simpler to organize than subsidiaries; however, they are not separate legal entities, so their results are consolidated with their parent

FIGURE 1

Theoretical Model of Local Density and Foreign Subsidiary Performance

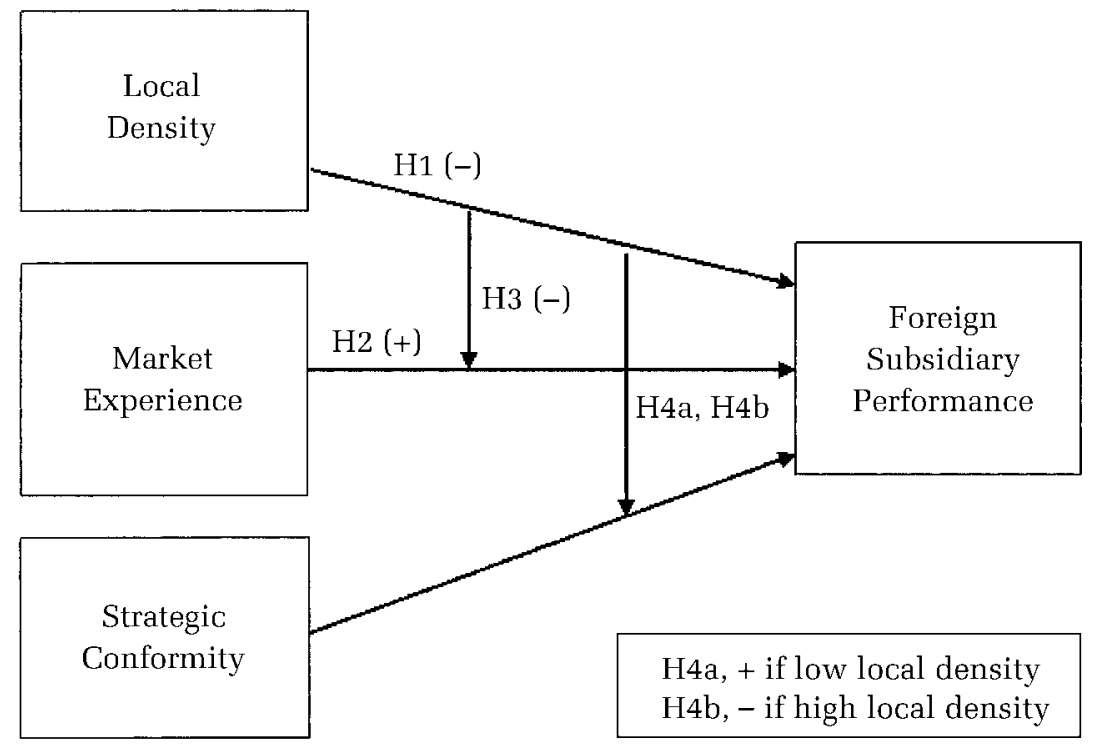


firms'. Foreign subsidiaries are legal entities that report separately from their parents and are subject to the same laws and regulatory requirements as host country banks. Moreover, foreign subsidiaries and domestic banks choose strategic positions from the same strategy domain.

Firm-specific data were from the Call Reports database, which is maintained by the Federal Deposit Insurance Corporation (FDIC). Our sample included foreign bank subsidiaries located in 12 metropolitan statistical areas (MSAs) in the United States. An MSA is "an area containing a recognized population nucleus and adjacent communities that have a high degree of integration with that nucleus" (Office of Management and Budget, 2000: 82228). MSAs define the most commonly used industry boundaries for studies involving commercial banks (Amel \& Rhodes, 1988; Barnett, Greve, \& Park, 1994; Berger, 1995). Our 12 MSAs included approximately 90 percent of all foreign bank subsidiaries over the studied time period. ${ }^{3}$

Our final sample included 83 foreign banking subsidiaries from 21 countries over four years, yielding 332 firm-year observations. Fifty-seven of the 83 foreign subsidiaries were from industrialized countries; the rest were from nonindustrialized countries. Although we included only foreign subsidiaries in the regression analysis, we used data for domestic firms to measure strategic conformity relative to local firms. Domestic banks were also included in the computation of local density.

\section{Variables}

To measure our dependent variable, foreign subsidiary performance, we used the return on assets (ROA) of a foreign subsidiary for a current year. ROA is a commonly used measure of bank performance in both strategy and finance research (Barnett et al., 1994; Deephouse, 1999; Mehra, 1996). Data were from the Call Reports database.

Local density was measured by the natural logarithm of the number of banks in the metropolitan statistical area where a foreign subsidiary operated in a particular year, based on FDIC's Call Report data.

Market experience was the difference between the first year of the study and the year when the foreign bank entered the local market in the United States. We took the natural logarithm. Data for market experience were obtained from Bankersalmanac. com, Moody's, and BankScope. On several occa-

\footnotetext{
${ }^{3}$ These were the only MSAs in which at least one foreign bank subunit was active in all four years.
}

sions, we contacted a parent bank to confirm the entry year.

To measure strategic conformity relative to local firms, we drew upon Deephouse's (1999) measure of strategic deviation, which is similar to the calculation used in Finkelstein and Hambrick's (1990) concept of strategic conformity. The measure of strategic conformity is based on bank asset strategies, reflecting the allocation of a bank's resources to certain product categories (e.g., Haveman, 1993; Mehra, 1996). In his study of the banking industry, Deephouse identified 11 asset strategy variables: "commercial loans, real estate loans, loans to individuals, agriculture loans, other loans and leases, cash, overnight money, securities, trading accounts, fixed assets, and other assets" (1999: 155). Each variable was adjusted for firm size and reported as a percentage of total assets. We removed other assets, agriculture loans, and trading accounts as asset strategies because only a small number of banks engaged in these activities in the particular MSAs that included foreign banks. These asset strategies produce a very low mean and low standard deviation that inflates a bank's strategy deviation even when it has a small percentage of assets in these categories. Therefore, our 8 asset strategies were commercial loans, real estate loans, loans to individuals, other loans and leases, cash, overnight money, securities, and fixed assets.

Our measure of strategic conformity compared a foreign subsidiary's asset strategy with that of the average asset strategy of local domestic banks in the same MSA. To develop the average asset strategy in a particular MSA, as a benchmark we used local domestic banks and did not include foreign subsidiaries; in effect, we assumed local banks were legitimate by virtue of their not being foreign. For a given foreign subsidiary $i$, we first measured its asset strategy (a) - that is, we measured $S_{a i}$. Each asset strategy was compared with the mean of the corresponding asset strategy of the local domestic banks in the MSA, $S_{L a}$, and divided by the corresponding standard deviation for each strategy variable $\sigma_{S L a}$. Using the values from each asset strategy variable, we then computed the total for each foreign subsidiary. We adopted this approach because, according to Finkelstein and Hambrick (1990), assessment of strategic decision patterns is best achieved by examining actions on multiple indicators of strategy, rather than on a single indicator. Lastly, we multiplied the sum of the absolute values (ABS) by -1 to convert the meaning from strategic deviation to strategic conformity. Strategic conformity (SC) for an individual foreign subsidiary was thus measured as: 


$$
S C_{i}=\left(\sum_{a=1}^{8} \operatorname{ABS}\left[\left(S_{a i}-\hat{S}_{L a}\right) / \sigma_{S L a}\right]\right) \times[-1] .
$$

The more negative the measure of strategic conformity, the less a foreign subunit conformed to the strategy of local firms; the less negative this measure, the more it conformed to local firms' strategy.

Our control variables included two micro and two macro measures. At the micro level, expense ratio indicated a foreign subsidiary's cost efficiency in a particular year. Following Deephouse (1999), we included this control variable because our study focused on a foreign subsidiary's asset strategies in terms of generating bank revenues. We did not examine banking strategies focused on cost efficiencies and therefore we needed to control for their presence. We measured the expense ratio as the annual ratio of interest and noninterest expenses to total assets using data from the Federal Reserve Board. We also included market share, which measured the foreign subsidiary's total deposits in the MSA as a share of deposits for all banks in the MSA per year; data were from the FDIC. This variable controlled for a subsidiary's relative size (and therefore market power) in its local environment, which might influence its financial performance.

At the macro level, we included market size, measured as total bank deposits (in trillions of dollars) in an MSA in a given year; data were from the FDIC. Market size was a predictor of the total revenue opportunities available to firms in a host country's local market. To control for differences in home countries that might affect performance, we included home GDP growth, the annual percent change in real gross domestic product for each foreign subsidiary's home country. World Development Indicators provided the data for this measure.
Lastly, we included year dummy variables for 1996, 1997, and $1998 .^{4}$

\section{RESULTS}

Table 1 presents summary statistics. We followed Irwin and McClelland (2001) by mean-centering all right-hand side variables at zero, with the exception of the dummy variables. Collinearity diagnostics were well within acceptable ranges when all interactions were included.

Since we had a cross-section time series panel data set, we tested for serial autocorrelation using the Hausman test. Its rejection suggested that a fixed-effects model would be a more appropriate regression technique than a random-effects model. Table 2 presents the results of our regression analysis, in which we used XTREG, FE, in STATA/SE 8.0. Model 1 of Table 2 includes only the control variables; model 2 adds local density; model 3 adds market experience and strategic conformity; and model 4 includes the interaction terms.

Hypothesis 1 predicts a negative relationship between local density and foreign subsidiary performance. In model 4 , the results indicate that the coefficient on local density is negative and significant $(\beta=-0.02, p>|t|=0.04)$, which supports Hypothesis 1 . Hypothesis 2 predicts a positive relationship between market experience and foreign subsidiary performance. In model 4 , the coefficient for market experience is positive and significant $(\beta=0.03, p>|t|=0.001)$, which provides empirical support for Hypothesis 2. Hypothesis 3 states

\footnotetext{
${ }^{4}$ Time-invariant macro or micro variables such as cultural distance, home country competitiveness, and number of MSAs in which a foreign bank operated in a host country were not included in our analysis because they dropped out of a fixed-effects regression model.
}

TABLE 1

Descriptive Statistics and Pairwise Correlations ${ }^{\text {a }}$

\begin{tabular}{|c|c|c|c|c|c|c|c|c|c|c|c|}
\hline Variable & Mean & s.d. & Minimum & Maximum & 1 & 2 & 3 & 4 & 5 & 6 & 7 \\
\hline 1. ROA & 0.01 & 0.01 & -0.09 & 0.06 & & & & & & & \\
\hline 2. Expense ratio & 0.07 & 0.02 & 0.02 & 0.24 & $-.24^{*}$ & & & & & & \\
\hline 4. Market size ${ }^{\mathrm{b}}$ & 20.11 & 13.29 & 0.08 & 42.00 & -.02 & .05 & $-.33^{*}$ & & & & \\
\hline 5. Home GDP growth & 0.04 & 0.05 & -0.15 & 0.27 & -.03 & -.00 & $.16^{*}$ & $-.12^{*}$ & & & \\
\hline 6. Local density & 189.03 & 124.96 & 2.00 & 382.00 & .05 & $-.17^{*}$ & $-.50^{*}$ & $.29 *$ & $-.12^{*}$ & & \\
\hline
\end{tabular}

${ }^{a}$ There are 332 observations (83 firms, 4 years). Means, standard deviations, minimums, and maximums were computed with raw data. Pairwise correlations are based on the format used in the actual regressions.

$\mathrm{b}$ Trillions of dollars. 
TABLE 2

Foreign Subsidiary Performance ${ }^{\mathrm{a}}$

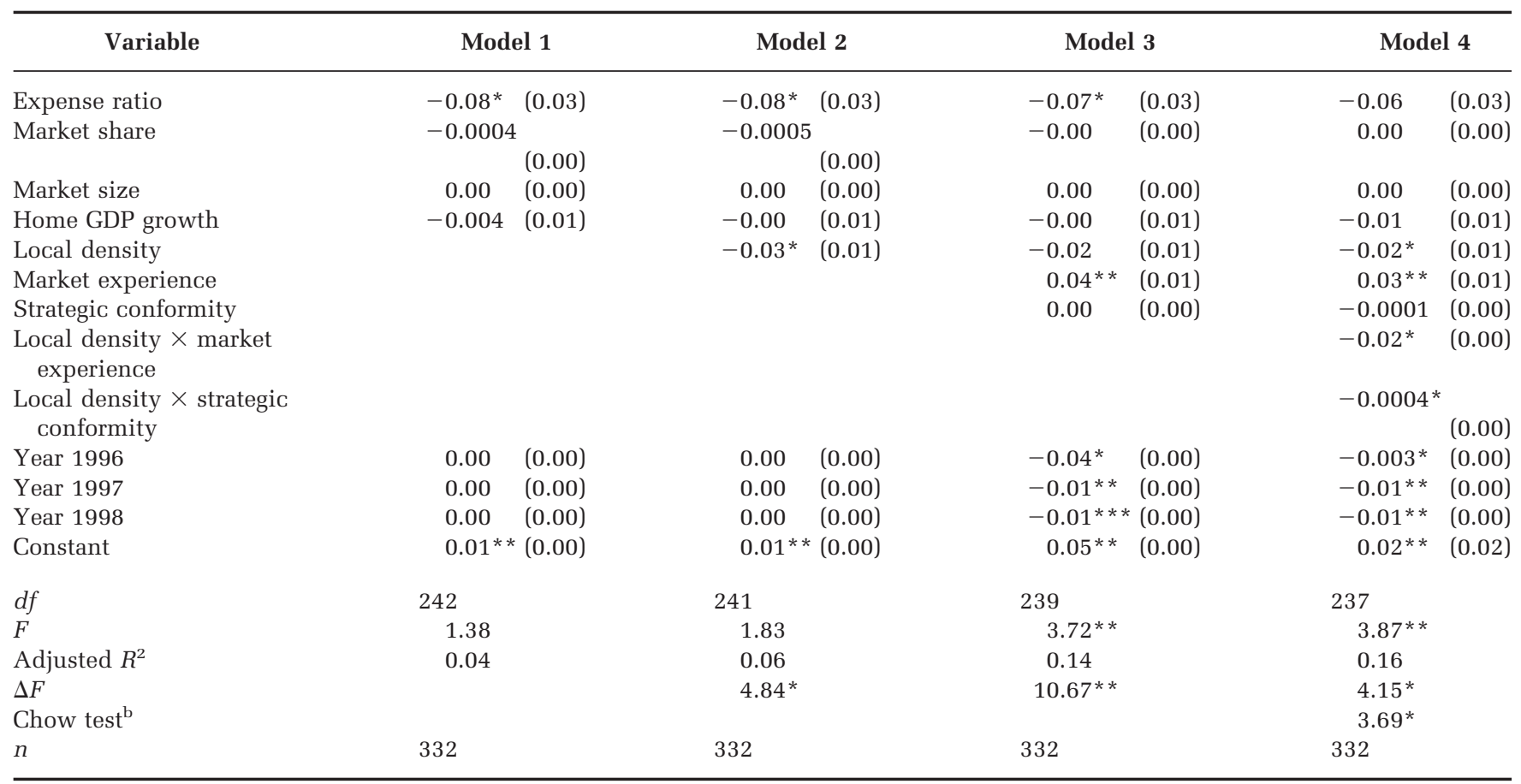

${ }^{a}$ Performance is measured as ROA. All independent and control variables, except dummy variables, are centered. Standard errors are reported in parentheses.

${ }^{\mathrm{b}}$ Density $\times$ market experience, and density $\times$ strategic conformity.

${ }^{*} p<.05$

${ }^{* *} p<.01$

that local density has a negative effect on the relationship between market experience and foreign subsidiary performance. In model 4 , the coefficient for the interaction between local density and market experience is negative and significant $(\beta=$ $-0.01, p>|t|=0.01$ ), supporting Hypothesis 3. A Chow test for the difference between models 3 and 4 (not reported in Table 2) was statistically significant $(F[2,237]=4.60$, prob $>F=0.011)$, indicating that local density moderated the relationship between market experience and foreign subsidiary performance, also supporting Hypothesis 3.

In panel A of Figure 2, we provide a graph of market experience and foreign subsidiary performance in high-, medium-, and low-density environments. Performance, market experience, and density were categorized as high at one standard deviation above the mean level and as low at one standard deviation below the mean. In high-density environments, low market experience produces a predicted ROA of -2.5 percent, whereas high market experience results in a predicted ROA of -0.9 percent. This represents a gain of 1.9 percentage points in predicted ROA between low and high levels of market experience. In low-density environments, low market experience produces a pre- dicted ROA of +1.7 percent, whereas high market experience results in a predicted ROA of +5.2 percent. This represents a gain of 3.5 percentage points in performance between low and high levels of market experience. These effects on ROA associated with different levels of market experience are substantial when compared with the average ROA for local domestic banks of 1.1 percent and foreign bank subsidiaries of 0.9 percent in the U.S. market during the period under study.

Note that the gain in predicted ROA owing to market experience is relatively smaller in high-density than in low-density environments $(+1.9$ versus +3.5 percentage points). As a result, the gap between the two lines in panel A widens from 4.2 percentage points for low market experience (1.7\% $-[-2.5 \%])$ to 5.8 percentage points for high-market experience $(5.2 \%-[-0.6 \%])$. Although market experience is positively related to predicted ROA, across density levels, the smaller ROA gap in high-density environments implies there is a flatter learning curve for foreign subsidiaries; that is, the financial payoff of market experience is lower in more cosmopolitan environments. In addition, foreign subsidiaries suffer less discriminatory treatment and therefore benefit less from market experience. 
FIGURE 2

Local Density as a Moderator of Market Experience and Strategic Conformity

(2a) Interaction: Local Density and Market Experience

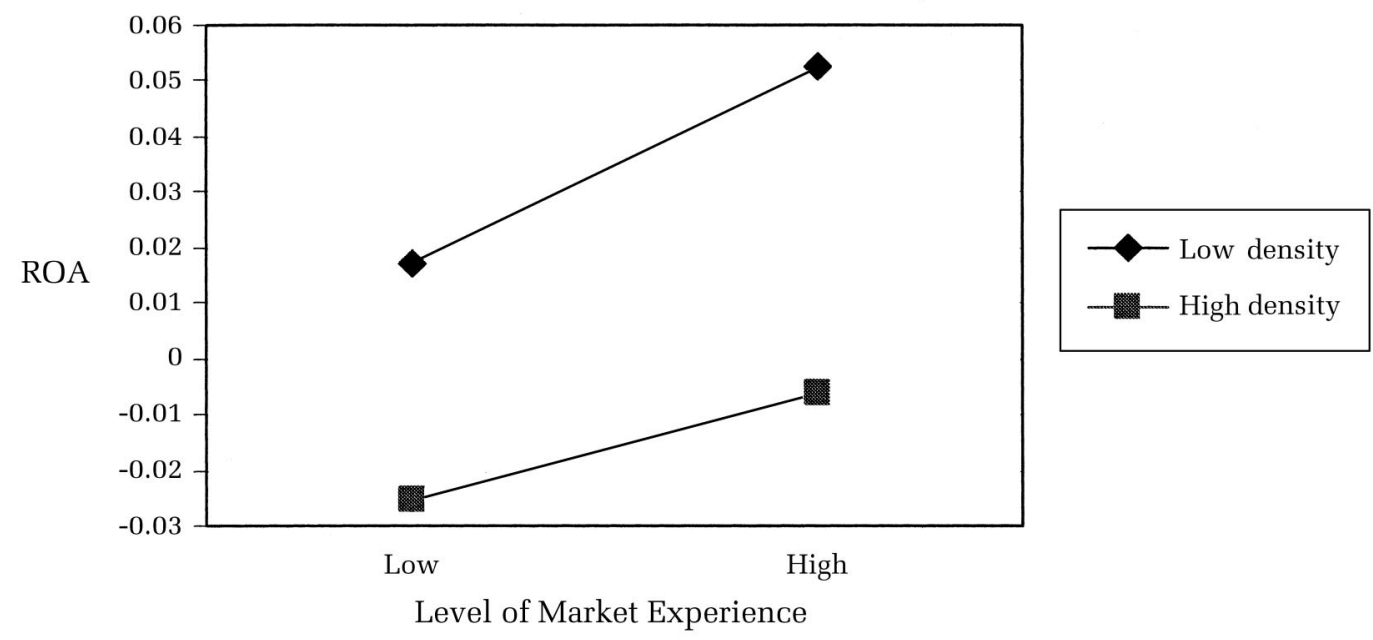

(2b) Interaction: Local Density and Strategic Conformity

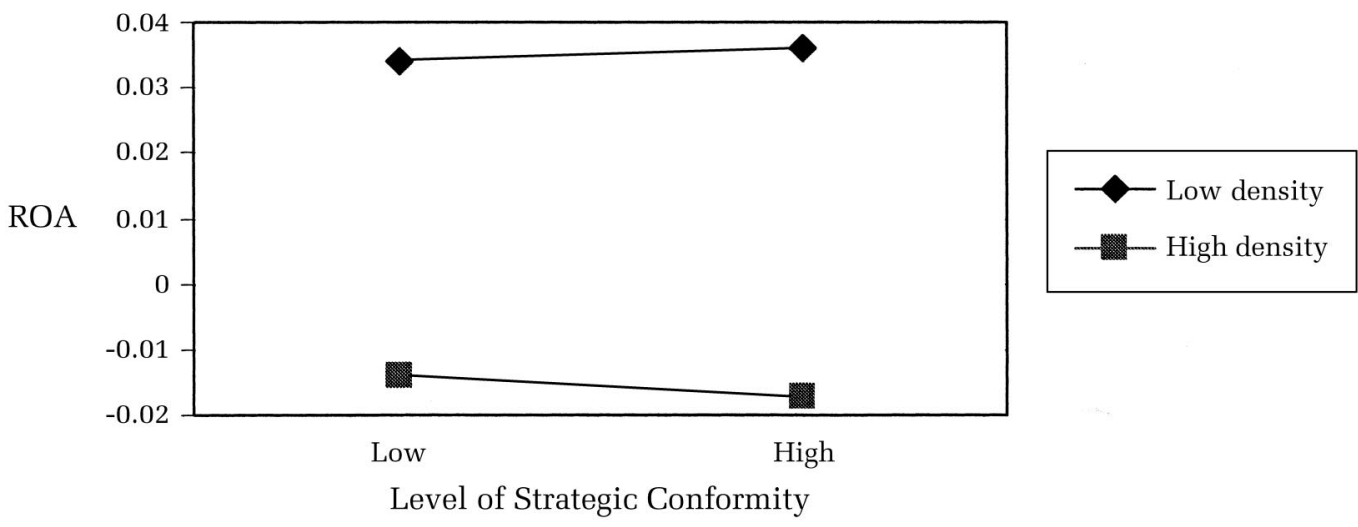

Hypothesis 4a predicts a positive relationship between strategic conformity and foreign subsidiary performance in low-density environments; Hypothesis $4 \mathrm{~b}$ predicts a negative relationship between strategic conformity and foreign subsidiary performance in high-density environments. In model 4 , the results indicate that the coefficient for the interaction of local density and strategic conformity is negative and significant $(\beta=-0.0004$, $p>|t|=0.04)$, but the coefficient for strategic conformity is not statistically significant $(\beta=$ $-0.0001, p>|t|=0.69$ ). A Chow test for the difference between models 3 and 4 (not reported in Table 2$)$ is statistically significant $(F[2,237]=3.94$, prob $>F=0.02$ ), indicating that local density moderated the relationship between strategic conformity and foreign subsidiary performance. The combined Chow test for both interactions is (not surprisingly) also statistically significant $(F[3,237]$ $=3.69$, prob $>F=0.01$ ).
We then conducted a simple slope test for the strategic conformity by local density interaction (Aiken \& West, 1991). The results indicated that in relatively low-density environments $(-1$ and -1.5 standard deviations below the mean level of density) the slopes of the interaction were not statistically significant. However, when local density was very low ( -2 s.d.'s), the slope of the interaction was significant at the 5 percent level $(t=2.09)$, providing conditional support for Hypothesis 4a. In relatively high-density environments $(+1$ and +1.5 s.d.'s above the mean), the slopes of both interactions were negative but only significant at the 5 percent level for +1.5 standard deviations above mean density. When local density was very high (+2 s.d.'s), the slope of the interaction was negative and significant at the 1 percent level $(t=-2.90)$, providing support for Hypothesis $4 \mathrm{~b}$.

In panel B of Figure 2, we present a graph of strategic conformity and predicted foreign subsid- 
iary performance in high- and low-local-density environments. We show the predicted performance for foreign subsidiaries with high (again, +1 s.d.) and low ( -1 s.d.) levels of strategic conformity, respectively. In high-density environments, low conformity resulted in a predicted ROA of -1.4 percent, whereas high conformity produced a predicted ROA of -1.7 percent, representing a loss of 0.3 percentage points from low to high conformity, ceteris paribus. In low-density environments, low conformity yielded a predicted ROA of +3.4 percent, whereas high conformity produced a predicted ROA of +3.6 percent. This represents a gain of 0.2 percentage points in performance from low to high conformity. These results reveal a spread of one-half percentage point $(+0.2 \%-[-0.3 \%])$ for predicted ROA.

Moreover, simple slope tests revealed the strength of the relationship in very high density (+2 s.d.) and very low density ( -2 s.d.) environments. We found that in very high density environments, there was a loss in predicted ROA of 0.6 percentage points in going from low to high strategic conformity. In very low density environments, predicted ROA gained 0.4 percentage points with movement from low to high strategic conformity, resulting in a spread of one percentage point $(+0.4 \%-$ [-0.6\%]) for predicted ROA. Following Cohen, Cohen, Aiken, and West (2003), we computed power statistics $(\alpha=.05$; effect size $=0.20)$. Our results indicate that statistical power was approximately 0.87 , which exceeded Cohen's (1988) recommended standard for a minimum power of 0.80 .

Lastly, as we noted in the theory development section, the density dependence literature has shown a U-shaped relationship between density and mortality rates. In the present study, we did not predict a U-shaped relationship between density and performance because the legitimacy of the banking sector is well established, even when local density is low. Nevertheless, we conducted an additional test that included a local density squared term. The coefficient on this variable was not significant, and coefficients on the key variables remained essentially unchanged (that is, no hypothesized relationship changed).

\section{DISCUSSION AND CONCLUSION}

Prior research has concluded that foreign subsidiaries incur a liability of foreignness when operating in a host country, reflected by their performing less well than domestic rivals. However, the role of local density as an indicator of competitive pressure, moderating the effect of previously studied antecedents of foreign subsidiary performance, has been overlooked. Our results strongly suggest that international scholars need to account for local density, and its exclusion may yield misleading results. Our study indicates that foreign subsidiaries face different challenges than do domestic firms and that local density influences conflicting pressures to conform or differentiate. Our results support our argument that the relationship between strategic conformity and foreign subsidiary performance depends on local density.

We infer from our results that as local density increases, competition intensifies and foreignness becomes less important in a local market, which has important implications for market experience and strategic conformity. The results of our study confirm that market experience is a valuable resource for a foreign subsidiary in general, but suggest that its value declines as local competition intensifies. The results also suggest that in highdensity environments, foreign subsidiaries that pursue a course of action focused on differentiation can achieve high performance. In low-density environments where liability of foreignness is an issue, foreign subsidiaries that deviate substantially from the asset strategies of local domestic firms may be perceived as less legitimate, causing local business and individuals, in turn, to be less willing to use these firms as financial service providers.

Another possible explanation is that in low-density environments, foreign subsidiaries do not deviate from domestic firms with respect to asset strategy because there is insufficient demand for some niche strategies. However, demand may be low because these niche strategies reside outside the range of legitimate strategies of local firms. Foreign subsidiaries that choose to pursue these strategies are likely to achieve low performance. Our results suggest that different courses of action with respect to strategic conformity yield different performance outcomes. ${ }^{5}$

If density reflected equilibrium between the supply of and demand for financial services, then competition would not differ across environments. However, our study, which controls for local market size, supports the density dependence argument that local density reflects local competition, which, in turn, strongly influences foreign subsid-

\footnotetext{
${ }^{5}$ We also found empirical support for Oliver's (1991) strategic responses. In her terminology, our results suggest that in low-density environments, high performance is achieved by "acquiescing" to local strategies, but in high-density environments, the strategic actions of foreign subsidiaries with strong performance can be viewed as "avoiding" or "defying."
} 
iary performance. Although liability of foreignness associated with unfamiliarity and discrimination should be a challenge for foreign subsidiaries in lower-density environments, we infer from our results that less local competition can enhance performance. In contrast, liability of foreignness should be less important in high-density environments, yet intense local competition presents a performance challenge for foreign subsidiaries. This observation suggests that in high-density environments foreign firms face a relatively low liability of foreignness but high competitive pressures, whereas in low-density environments, the reverse occurs.

Although ROA is a reasonable and common measure of banking performance, it is possible that foreign subsidiaries, particularly in their early years in a host market, might focus on growth as a strategic objective, rather than financial performance. A market penetration strategy that maximized growth in bank assets or bank deposits-for example, by offering more competitive (lower) lending rates than rivals-would negatively affect ROA. Since growth as a strategic objective is distinct from and may come at the expense (at least initially) of financial performance (Barney, 2002), we might expect a market penetration strategy to yield a pattern of findings opposite to our hypothesized relationships for ROA, and in fact, that is the case.

In a supplemental analysis (available from the authors), we tested asset growth rates and deposit growth rates instead of ROA as our dependent variable. ${ }^{6}$ The key results were that market experience was negatively related to asset (or deposit) growth, which supported the notion that less-experienced foreign subsidiaries emphasized growth during the early years. The coefficient on strategic conformity was positive, but only marginally significant ( $p$ $<.10$ ). However, the local density by strategic conformity interaction was positive and significant at the 5 percent level, as expected. In higher-density environments, for example, a foreign subsidiary can achieve higher growth by conforming to the asset strategies of local firms, yet this implies facing increased competition and thin margins. Thus, to attract customers in highly competitive environments, foreign subsidiaries must lower their lending interest rates, adversely affecting ROA. We con-

\footnotetext{
${ }^{6}$ We tested both the absolute annual growth rate in foreign subsidiary deposits in an MSA and the growth rate relative to the growth rate of total MSA deposits. Because total MSA assets were not available, we could only test the absolute annual growth rate in foreign subsidiary assets.
}

clude that our supplemental analysis using growth as a dependent variable has important implications for financial performance and provides some support for DeYoung and Nolle's (1996) explanation as to why foreign subsidiaries in the United States have lower financial performance than domestic rivals.

Our study explored the relationship between local density and foreign subsidiary performance and integrated insights from the density dependence and liability of foreignness literatures. We found that local density is negatively related to foreign subsidiary performance and that market experience is less beneficial in high-density environments. Strategic conformity enhances performance in lowdensity environments but adversely affects performance in high-density environments.

Our results support the argument that the relationship between strategic conformity and foreign subsidiary performance depends on local density. The results for strategic conformity are especially noteworthy given that the U.S. banking sector is highly regulated, which reduces the size of the strategic domain for foreign subsidiaries and domestic banks compared with less regulated industries. As such, our sample provides a conservative test of our hypotheses on strategic conformity.

The findings from our study suggest that the competitive and institutional pressures facing foreign subsidiaries are interrelated. The optimal degree of strategic conformity depends on the environment in which a foreign subsidiary operates, demonstrating that different actions by a foreign subsidiary's managers can have important implications for performance, which is consistent with Oliver's (1991) institutional strategy arguments.

Our study contributes to the international management literature in several ways. We build upon work on liability of foreignness by integrating the effect of density dependence. Specifically, we incorporated differences in local density within a host country, unlike previous studies, which have examined liability of foreignness at the national level. Our results extend the work of Zaheer (1995), Zaheer and Mosakowski (1997), Miller and Parkhe (2002), and Nachum (2003) by drawing upon previous findings about density dependence to show that local density is an important variable that cannot be ignored in explaining performance, especially when foreign subsidiaries operate in different local markets within a host country. Second, our findings also extend this literature by showing that the relationships between strategic conformity and market experience and foreign subsidiary performance depend on local density. Although we focused on foreign subsidiaries, our findings also 
build the well-established structure-conduct-performance literature, in which little prior attention has been devoted to local density as a measure of local competitive pressures or to local density's interactions with strategic conformity and market experience.

We also contribute to the international management literature by introducing the concept of strategic conformity to an international context. Specifically, we theorized that for foreign subsidiaries, local density influences the conflicting pressures to conform to and differentiate from local firms by influencing the range of legitimate strategies. Thus, we help resolve the "differentiation versus conformity dilemma" facing foreign subsidiaries with a theoretical argument for a contingent relationship between strategic conformity and foreign subsidiary performance, driven by local density.

We acknowledge that the present study has limitations. First, we focused on the U.S. banking market (a mature population industry), in which banking services have been provided for over 100 years. Our sample of foreign subsidiaries operated in local environments with medium or high density levels, but not in low-density markets in the true spirit of density dependence models. In our study, density was low in a relative sense-for example, Laredo, Texas, or Fort Lauderdale, Florida, had low density relative to the high density of New York City.

Second, the U.S. financial system tends to be market oriented, despite the large number of banking organizations it contains. Therefore, an opportunity for future research is to examine the moderating effect of local density in countries that differ institutionally from the United States, such as developing countries and those with emerging markets. In some of these countries, foreign firms may have an advantage rather than a liability of foreignness, a condition that would also have implications for the effect of local density on foreign subsidiary performance.

Third, population density varies from industry to industry. In the U.S. banking sector, some of the high-density environments have local density that exceeds 100 organizations. In other industries, high local density may be classified as fewer than 10 organizations (consider, for example, the tendency of automotive assemblers to locate in different U.S. states). Expanding our analysis to other industries would therefore be a useful extension of our arguments.

The present study focused on local domestic firms as targets of comparability for foreign subsidiaries. However, foreign subsidiaries can choose to be similar to or different from other foreign subsidiaries, either from the same or other home coun- tries, rather than target local firms. A preliminary analysis suggested that strategic conformity relative to all other foreign subsidiaries had no effect on subsidiary performance. Nevertheless, a more extensive investigation of strategic conformity relative to particular subgroups (especially under high uncertainty) and the corresponding determinants may shed additional light on the behavior of foreign subsidiaries. We leave this question for future research.

In sum, the performance of foreign subsidiaries depends on local density. Although there is no guarantee that a foreign subsidiary will be able to outperform local firms, our study shows that a subsidiary can overcome liability of foreignness and achieve high performance relative to other foreign rivals by achieving a fit between its strategy, market experience, and local environment within the host country.

\section{REFERENCES}

Aiken, L., \& West, S. 1991. Multiple regression: Testing and interpreting interactions. Newbury Park, CA: Sage.

Amel, D. F., \& Rhodes, S. 1988. Strategic groups in banking. Review of Economics and Statistics, 70: 685689.

Barkema, H., Bell, J., \& Pennings, J. 1996. Foreign entry, cultural barriers, and learning. Strategic Management Journal, 17: 151-166.

Barnett, W. P., Greve, H., \& Park, D. Y. 1994. An evolutionary model of organizational performance. Strategic Management Journal (winter special issue), 15: 11-28.

Barney, J. 1991. Firm resources and sustained competitive advantage. Journal of Management, 17: 99120.

Barney, J. 2002. Gaining and sustaining competitive advantage (2nd ed.). Upper Saddle River, NJ: Prentice-Hall.

Baum, J., \& Mezias, S. J. 1992. Localize competition and organizational failure in the Manhattan hotel industry 1898-1990. Administrative Science Quarterly, 37: $580-604$.

Baum, J., \& Singh, J. 1994. Organizational niches and the dynamics of organizational mortality. American Journal of Sociology, 100: 346-380.

Beaverstock, J., Smith, R., \& Taylor, P. 2003. The global capacity of a world city: A relational study of London. In E. Kofman \& G. Youngs (Eds.), Globalization: Theory and practice (2nd ed.): 223-236. London: Continuum.

Berger, A. 1995. The profit-structure relationship in banking: Tests of market-power and efficient-struc- 
ture hypotheses. Journal of Money, Credit, and Banking, 27: 404-431.

Cannon, H., \& Yaprak, A. 2002. Will the real-world citizen please stand up! The many faces of cosmopolitan consumer behavior. Journal of International Marketing, 10(4): 30-52.

Carroll, G., \& Hannan, M. T. 1989. Density dependence in the evolution of populations in newspaper organizations. American Sociological Review, 54: 524-441.

Cohen, J. 1988. Statistical power analysis for the behavioral sciences (2nd ed.). Mahwah, NJ: Erlbaum.

Cohen, J., Cohen, P., West, S., \& Aiken, L. 2003. Applied multiple regression/correlation analysis for the behavioral sciences (3rd ed.). Mahwah, NJ: Erlbaum.

Deephouse, D. 1999. To be different, or to be the same? It's a question (and theory) of strategic balance. Strategic Management Journal, 20: 147-166.

Delios, A., \& Beamish, P. 2001. Survival and profitability: The roles of experience and intangible assets in foreign subsidiary performance. Academy of Management Journal, 44: 1028-1038.

DeYoung, R., \& Nolle, D. 1996. Foreign owned banks in the United States: Earning market share or buying it? Journal of Money, Credit, and Banking, 28: 622636.

DiMaggio, P., \& Powell, W. 1983. The iron cage revisited: Institutional isomorphism and collective rationality on organization fields. American Sociological Review, 48: 147-160.

Dunning, J. 1977. The location of economic activity and the multinational enterprise: Search for an eclectic approach. In B. Ohlin, P. Hesselborn, \& P. Wiskman (Eds.), The international allocation of economic activity: 395-418. London: Macmillan.

Eden, L., \& Miller, S. R. 2004. Distance matters: Liability of foreignness, institutional distance and ownership strategy. In M. Hitt \& J. Cheng (Eds.), Advances in international management, vol. 16: 187-221. New York: Elsevier.

Finkelstein, S., \& Hambrick, D. 1990. Top-managementteam tenure and organizational outcomes: The moderating role of managerial discretion. Administrative Science Quarterly, 35: 484-503.

Hannan, M. T., \& Carroll, G. R. 1992. Dynamics of organizational populations: Density, legitimacy, and competition. New York: Oxford University Press.

Hannan, M. T., \& Carroll, G. R. 2000. The demography of corporations and industries. Princeton, NJ: Princeton University Press.

Hannan, M. T., Carroll, G., Dundon, E., \& Torres, J.C. 1995. Organizational evolution in a multinational context: Entries of automobile manufacturers in Belgium, Britain, France, Germany and Italy. American Sociological Review, 60: 509-528.

Hannan, M. T., \& Freeman, J.H. 1977. The population ecology of organizations. American Journal of Sociology, 83: 929-984.

Hannan, M. T., \& Freeman, J. H. 1987. The ecology of organizational founding: American labor unions, 1836-1985. American Journal of Sociology, 92: 910-943.

Hannan, M. T., Ranger-Moore, J., \& Banaszak-Holl, J. 1990. Competition and the evolution of organizational size distributions. In J. Singh (Ed.), Organizational evolution-New directions: 246-268. Newbury Park, CA: Sage.

Hannan, T. H. 1991. Bank commercial loan markets and the role of market structure: Evidence from surveys of commercial lending. Journal of Banking and Finance, 15: 133-149.

Hannerz, U. 1990. Cosmopolitans and locals in world culture. Theory, Culture and Society, 7: 237-251.

Haveman, H. 1993. Follow the leader: Mimetic isomorphism and entry into new markets. Administrative Science Quarterly, 38: 593-627.

Hymer, S. 1976. The international operations of national firms: A study of direct foreign investment. Cambridge, MA: MIT Press.

Irwin, J. R., \& McClelland, G. H. 2001. Misleading heuristic and moderated multiple regression models. Journal of Marketing Research, 38: 100-109.

Johanson, J., \& Vahlne, J.-E. 1977. The internationalization process of the firm-A model of knowledge development and increasing foreign market commitments. Journal of International Business Studies, 8(1): 23-32.

Kostova, T., \& Zaheer, S. 1999. Organizational legitimacy under conditions of complexity: The case of the multinational enterprise. Academy of Management Review, 24: $64-81$.

Li, J. 1995. Foreign entry and survival: Effects of strategic choices on performance in international markets. Strategic Management Journal, 16: 333-351.

McNamara, G., Deephouse, D., \& Luce, R. 2003. Competitive positioning within and across a strategic group structure: The performance of core, secondary and solitary firms. Strategic Management Journal, 24: 161-181.

Mehra, A. 1996. Resource and market based determinants of performance in the U.S. banking industry. Strategic Management Journal, 17: 307-322.

Merton, R. K. 1957. Social theory and social structure. New York: Free Press.

Meyer, J., \& Rowan, B. 1977. Institutionalized organizations: Formal structure as myth and ceremony. American Journal of Sociology, 83: 340-363.

Mezias, J. 2002. Identifying liability of foreignness and strategies to minimize their effects: The case of labor lawsuit judgments in the United States. Strategic Management Journal, 23: 229-344. 
Mezias, J., \& Mezias, S. 2000. Resource partitioning, the founding of specialist firms, and innovation: The American feature film industry, 1912-1929. Organization Science, 11: 306-322.

Miller, S. R., \& Parkhe, A. 2002. Is there a liability of foreignness in global banking? An empirical test of banks' X-efficiency. Strategic Management Journal, 23: 55-75.

Mitchell, W., Shaver, J. M., \& Yeung, B. 1994. Foreign entrant survival and foreign market share: Canadian companies' experience in United States medical sector markets. Strategic Management Journal, 15: 555-567.

Nachum, L. 2003. Liability of foreignness in global competition? Financial service affiliates in the city of London. Strategic Management Journal, 24: 11871208.

Office of Management and Budget. 2000. Federal registry: Standards for defining metropolitan and micropolitan statistical areas. Washington, DC: National Archives and Records Administration.

Oliver, C. 1991. Strategic responses to institutional processes. Academy of Management Review, 16: 145179 .

Oliver, C. 1997. Sustaining competitive advantage: Combining institutional and resource-based views. Strategic Management Journal, 18: 697-713.

Porac, J., Thomas, H., \& Baden-Fuller, C. 1989. Competitive groups as cognitive communities: The case of Scottish knitwear manufacturers. Journal of Management Studies, 26: 397-416.

Porter, M. 1980. Competitive strategy. New York: Free Press.

Porter, M. 1986. Competition in global industries. Boston: Harvard Business School Press.

Porter, M. 1990. The competitive advantage of nations. New York: Free Press.

Reger, R. K., \& Huff, A. S. 1993. Strategic groups: A cognitive perspective. Strategic Management Journal, 14: 103-124.

Rosenzweig, P., \& Singh, J. 1991. Organizational environments and the multinational enterprise. Academy of Management Review, 16: 340-61.

Ruef, M., \& Scott, W. R. 1998. A multidimensional model of organizational legitimacy: Hospital survival in changing institutional environments. Administrative Science Quarterly, 43: 877-904.

Scott, A. 1995. Institutions and organizations. Thousand Oaks, CA: Sage.

Shaver, J. M., Mitchell, W., \& Yeung, B. 1997. The effect of own-firm and other-firm experience on foreign direct investment survival in the United States, 1987-92, Strategic Management Journal, 18(10): 811-824.

Shimp, T., \& Sharma, S. 1987. Consumer ethnocentrism: Construction and validation of the CETSCALE. Journal of Marketing Research, 24: 280-289.

Singh, J., Tucker, D., \& House, R. 1986. Organizational legitimacy and the liability of newness. Administrative Science Quarterly, 31: 171-193.

Sirmon, D., Hitt, M., \& Ireland, R. D. 2007. Managing firm resources in dynamic environments to create value: Looking inside the black box. Academy of Management Review: In press.

Spender, J.-C. 1989. Industry recipes: The nature and source of managerial judgment. Oxford, U.K.: Basil Blackwell.

Tschoegl, A. 1987. International retail banking as a strategy: An assessment. Journal of International Business Studies, 18(2): 67-88.

UNCTAD. 2004. World investment report 2004: The shift towards services. New York and Geneva: United Nations.

Xu, D., \& Shenkar, O. 2002. Institutional distance and the multinational enterprise. Academy of Management Review, 27: 608-618.

Zaheer, S. 1995. Overcoming the liability of foreignness. Academy of Management Journal, 38: 341-363.

Zaheer, S., \& Mosakowski, E. 1997. The dynamics of the liability of foreignness: A global study of survival in financial services. Strategic Management Journal, 18: 439-464.

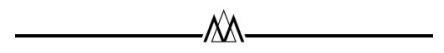

Stewart R. Miller (stewart.miller@mccombs.utexas.edu) is an assistant professor at the McCombs School of Business at the University of Texas at Austin. He received his Ph.D. in strategic management from Indiana University. His research interests include liability of foreignness and internationalization processes.

Lorraine Eden (leden@tamu.edu) is professor of management in the Mays Business School at Texas A\&M University. She received her Ph.D. in economics from Dalhousie University. Her research focuses on multinational enterprises, particularly in the areas of liability of foreignness, transfer pricing and international taxation, North American economic integration, and the North American auto industry.

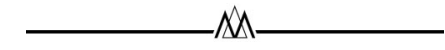


Copyright of Academy of Management Journal is the property of Academy of Management and its content may not be copied or emailed to multiple sites or posted to a listserv without the copyright holder's express written permission. However, users may print, download, or email articles for individual use. 